\title{
CHARACTERISTICS OF SEMINAL PLASMA PROTEINS IN RELATION TO FERTILITY OF SHEEP UNDER EGYPTIAN CONDITIONS
}

\section{I.I. Abdel-Mageed and SH.M. Dessouki}

\author{
Animal Production Department, Faculty of Agriculture, Cairo University, 12613, Giza, Egypt, E-mail: \\ sherifd2002@agr.cu.edu.eg
}

Received: $13 / 2 / 2017$

\section{SUMMARY}

This study aimed to investigate the relationship between the protein profile of seminal plasma and fertility rate of some subtropical sheep breeds. By using artificial vagina three ejaculates were collected from ten mature rams(Ossimi (3), crosses of Ossimi $\times$ Finnish Landrace and Suffolk (3), and Assaf (4) breeds). Semen characteristics e.g. (ejaculate volume, semen density, mass motility, individual motility (\%), live sperm (\%), abnormalities (\%) and sperm concentration were determined after collection. Seminal plasma proteins were identified by one dimensional polyacrylamide gel electrophoresis (SDS-PAGE) method. Semen density and sperm concentration were significantly $(p<0.05)$ higher in both Assaf and Crossbreds of Ossimi. Abnormal sperm percentage revealed a significant increase in Ossimi semen (9.80\%) compared to its crossbreds and Assaf semen (7.83 and $6.97 \%$, respectively).A total of 14 protein bands were visualized in ram seminal plasma samples. Protein bands 78-85 and 97-107 KDa were present in all studied breeds. However, the protein band of $40 \mathrm{KDa}$ showed an increase in the percent of appearance in Ossimi crossbreds and Assaf (100\%) compared to Ossimi breed (33\%).It is clear that Assaf rams proved a potential capability for their breeding ability under Egyptian conditions. Therefore, it may be recommended to incorporate this breed in breeding programs of sheep in Egypt.

Keywords: rams, Ossimi, Assaf, semen, motility, protein, electrophoresis

\section{INTRODUCTION}

Sheep production has a distinguished position in the agricultural system in Egypt. Its population reached 5,450,000 head in 2013 and contributed to the local production of red meat in Egypt by about 7 $\% \quad$ (FAO, 2013). Following selection and crossbreeding trials conducted in various countries, the Assaf provide a set of genotypes that are adapted to Middle East conditions and it can be tailored to a range of management conditions (Galal et al., 2008).

Male fertility in ruminants is much more important in reproductive programs than female fertility (Oliveira et al., 2012), as a result of its capability for mating a large number of females. This focuses to the importance of male rams on the breeding strategies of ruminants on the national level. One important element for selection of breeding rams for either natural mating or artificial insemination relies upon semen quality evaluation (RodríguezMartínez, 2003).Semen quality is very important factor affecting rams reproduction efficiency (Aller $e t$ al.,2012).

Seminal plasma is important to maintain spermatozoa motility, viability and fertility in bulls (Baas et al., 1983; Cross, 1993; Killian et al., 1993; Bellin et al., 1996 and Jobim et al., 2004) and rams (Ashworth et al., 1994; Graham, 1994 and Maxwell et al., 1997) and for resisting cold shock damage (Pursel et al., 1973; Vischwanath and Shannon, 1997 and Barrios et al., 2000). In addition, seminal plasma prevents premature capacitation of sperm (Eng and
Oliphant, 1978) and protects sperm from peroxidative damage (Schoneck et al., 1996).In addition, it has also implications in the regulation of acrosome reaction (Cross, 1993; Florman and First 1988) and in the regulation of $\mathrm{Ca}^{2}$ uptake by sperm (Clark et al., 1993).

Baas et al. (1983) and Jobim et al. (2004) concluded that seminal plasma has a deleterious effect on bovine spermatozoa during storage at ambient temperatures. However, it had no related effect on freezability. Decreasing sperm-bound bovine seminal plasma proteins (BSP) after cryopreservation; may indicate its' role during cryopreservation process (Nauc and Manjunath 2000).

Seminal plasma proteins of several species were separated, described and analyzed using TwoDimensional Polyacrylamide Gel Electrophoresis (2D-PAGE) (Killian et al., 1993; Frazer et al.,1996; Mortarino et al., 1998 and Brandon et al., 1999). Protein composition of seminal plasma has important effects on sperm function and varies according to genotype (Cross, 1993; Mortarino et al., 1998; Villemure et al., 2003 and Boisvert et al., 2004).

Many seminal plasma proteins have been identified and characterized (Ayyagari et al., 1987; Frazer et al., 1996 and Moreau and Manjunath, 1999). Some of the seminal proteins were found to be associated with fertility in various species (Ayyagari et al., 1987; Manjunath and Sairam, 1987 and Kraus et al., 2001). Bovine seminal plasma (BSP) contains a family of major proteins, designated BSP-A1/-A2 
and BSP-A3, with apparent molecular masses ranging from 15 to $17 \mathrm{kDa}$, and the $\mathrm{BSP}-30 \mathrm{kDa}$ protein with molecular mass of $28-30 \mathrm{kDa}$, collectively called BSP proteins (Manjunath, 1984). The biological properties of BSP proteins have been extensively studied (Manjunath and Therien, 2002). However, there is a little information available regarding to buffalo seminal plasma proteins.

Four seminal plasma proteins were found to be associated with bull fertility (Killian et al., 1993). Two of these proteins, $26 \mathrm{kDa}(\mathrm{p} I 6.2)$ and $55 \mathrm{kDa}$ ( $\mathrm{p} I$ 4.5), were associated with high-fertility bulls, whereas the other two, $16 \mathrm{kDa}(\mathrm{p} I 4.1)$ and $6.7 \mathrm{kDa}$, respectively, were more frequent in low-fertility bulls. The $55 \mathrm{kDa}(\mathrm{p} I$ 4.5) bovine seminal plasma protein was identified as an Osteopontin (Cancel et al., 1997) and the $26 \mathrm{kDa}(\mathrm{p} I$ 6.2) protein as a lipocalin-type prostaglandin-D synthase (Gerena et al., 1998). Seminal plasma ribonuclease (14 kDa) was present in higher concentrations in bulls with poor post-thaw semen quality (Roncoletta et al., 2002).

Voglmayr et al. (1982) and Hammerstedt and Parks (1987) demonstrated that the changes in sperm membrane proteins and glycoproteins of rams during epididymal transit have been documented by SDSPAGE studies however, the ovine seminal plasma proteins are still poorly understood and described in previous studies with SDS-PAGE. Barrios et al. (2000) mentioneda total of 20 bands in ovine seminal plasma. The objective of this work is to correlate between the seminal plasma protein and fertility rate of some subtropical sheep breeds.

\section{MATERIALS AND METHODS}

Ten rams, related to a commercial sheep flock, located in Delta region of north Egypt [Ossimi (3 rams), Ossimi crosses with Finnish Landrace and Suffolk (3 rams), and Assaf (4 rams)] were used in this study. Age of such rams ranged between 2 and 4 years. Ossimi ewes came in heat were introduced to the rams to be hand-mated twice, 12-hours apart. Animals were kept loose in semi-shade pens, where drinking water was made available all day time. Clover hay plus concentrate feed mixture $(12 \% \mathrm{CP}$ and $65 \% \mathrm{TDN}$ ) were offered to animals according to their body weights (NRC, 1985).

Semen was collected from rams by using artificial vagina (three samples) each two weeks apart immediately before mating. Physical characteristics of ram semen were determined (ejaculate volumesemen density-mass motility-individual motility $\%$ live $\%$-sperm abnormalities $\%$ - sperm concentration) immediately after collection. Fresh semen samples were centrifuged at $5000 \mathrm{rpm}$ for 10 minutes. The supernatants were transferred into glass vials and stored at $-20^{\circ} \mathrm{C}$ until biochemical analysis. Seminal plasma proteins were recognized for each ramusing one dimensional polyacrylamide gel electrophoresis.

Samples of frozen seminal plasma $(n=30)$ were used after thawing at room temperature to determine molecular weight of seminal plasma protein. For protein denaturation, $950 \mu$ of sample buffer $(3.55 \mathrm{ml}$ deionized water, $1.25 \mathrm{ml} 0.5 \mathrm{M}$ Tris-Hcl, $\mathrm{pH} 6.8,2.5$ $\mathrm{ml}$ Glycerol and $2 \mathrm{ml} 10 \%$ (w/v) Sodium Dodecyl Sulphate SDS) was added to $50 \mu$ of $\beta$ Mercaptoethanol. Fifteen $u$ of seminal plasma samples were added to $2 \mathrm{u}$ of loading buffer $(3.55 \mathrm{ml}$ deionized water, $1.25 \mathrm{ml} 0.5 \mathrm{M}$ Tris-Hcl, $\mathrm{pH} 6.8,2.5$ $\mathrm{ml}$ Glycerol, $2 \mathrm{ml} 10 \%$ (w/v) SDS and $0.2 \mathrm{ml} 0.5 \%$ (W/V) Bromophenol blue) was prepared. Running buffer was prepared by using $30.3 \mathrm{gm}$ Tris base, 144 gm Glycine and $10 \mathrm{gm}$ SDS up to $1000 \mathrm{ml}$ of deionized water.

The gel was prepared using $7.2 \mathrm{ml} \mathrm{H}_{2} \mathrm{O}, 7.5 \mathrm{ml}$ of $1.5 \mathrm{M}$ Tris- $\mathrm{HCl}, \mathrm{pH} 8.8,0.15 \mathrm{ml} \mathrm{20 \%}$ (w/v) SDS, $15.0 \mathrm{ml}$ Acrylamide/Bis-acrylamide $(30 \% / 0.8 \% \mathrm{w} / \mathrm{v})$, $0.15 \mathrm{ml}$ of $10 \%(\mathrm{w} / \mathrm{v})$ ammonium persulfate (APS) and $0.02 \mathrm{ml}$ TEMED.

The gel was placed in Petri dish for staining with Comassie brilliant stain (40\% methanol $20 \mathrm{ml}, 10 \%$ acetic acid $5 \mathrm{ml}, 0.025 \%$ Comassie $0.012 \mathrm{gm}$ and up to $50 \mathrm{ml}$ of deionized water) and was shaken for 6 hours. The molecular weight of each band representing specific protein in each lane was determined using Uvidoc software (version 12.4, England).

For each ram, the mean of all three collections was estimated. Data of the semen evaluation were analyzed using the SAS GLM procedure (SAS, 2004). Fertility rate at lambing was analyzed using the chi-square CATMOD procedure. Duncan's multiple range test was used to detect differences among means. The significance level was set at $\mathrm{P}<0.05$.

\section{RESULTS AND DISCUSSION}

Semen characteristics and fertility rate of the different breeds and crosses are shown in Table (1). The results showed insignificant increase in Assaf semen volume compared to Ossimi breed or Ossimi crosses. Many authors (Tabbaa et al., 2006; Mahmoud, 2013 and Miloud and Karima, 2015) recorded lower values of semen volume compared to those recorded in this study. Mahmoud (2013) recorded lower semen volume $(1.1 \mathrm{ml})$ in Ossimi rams. Moreover, Tabbaa et al. (2006) on Awassi breed and Miloud and Karima (2015) on Ouled Djellal breed reported lower values for semen volume $(1.12-1.21 \mathrm{ml})$. On the other hand, Assaf showed similar volume $(1.75 \mathrm{ml})$ to that recorded by Olah et al. (2013) using Ile de France breed in autumn and spring, but it was lower than that recorded in winter $(1.89 \mathrm{ml})$.

Semen density (0-3) and sperm concentration $\left(10^{9} / \mathrm{ml}\right)$ were high $(\mathrm{P}<0.05)$ in both Assaf and Ossimi crossbreds. Olah et al .(2013) reported lower value of Suffolk semen density (2.35) in summer compared to that recorded on Ossimi crossbreds in the present study (2.83). Moreover, sperm concentrations $\left(2.10-3.40 \times 10^{9} / \mathrm{ml}\right)$ (Table 1) were lower than the number $\left(4.9 \times 10^{9} / \mathrm{ml}\right)$ recorded by 
Miloud and Karima (2015). Also, Mahmoud (2013) on Ossimi breed, recorded higher concentration (2.9 $\times 10^{9} / \mathrm{ml}$ ) than that recorded for Ossimi rams in the present study $\left(2.1 \times 10^{9} / \mathrm{ml}\right)$.

Table 1. Semen characteristics and fertility rate of subtropical sheep as affected by breed of rams

\begin{tabular}{|c|c|c|c|}
\hline \multirow{2}{*}{ Semen Traits } & \multicolumn{3}{|c|}{ Breed } \\
\hline & Ossimi & Ossimi crossbreds & Assaf \\
\hline Volume(ml) & $1.50 \pm 0.15$ & $1.67 \pm 0.15$ & $1.75 \pm 0.13$ \\
\hline Semen Density (0-3) & $1.83 \pm 0.15^{b}$ & $2.83 \pm 0.15^{\mathrm{a}}$ & $2.87 \pm 0.13^{\mathrm{a}}$ \\
\hline Mass Motility (0-5) & $1.67 \pm 0.19^{\mathrm{c}}$ & $3.17 \pm 0.19^{b}$ & $4.75 \pm 0.17^{\mathrm{a}}$ \\
\hline Individual Motility (\%) & $60.00 \pm 2.81^{\mathrm{c}}$ & $80.00 \pm 2.81^{b}$ & $91.25 \pm 2.44^{\mathrm{a}}$ \\
\hline Live Sperm (\%) & $70.90 \pm 1.40^{\mathrm{c}}$ & $81.67 \pm 1.40^{\mathrm{b}}$ & $89.87 \pm 1.21^{\mathrm{a}}$ \\
\hline Abnormal Sperm (\%) & $9.80 \pm 0.64^{\mathrm{a}}$ & $7.83 \pm 0.64^{b}$ & $6.97 \pm 0.56^{\mathrm{c}}$ \\
\hline Concentration $\left(10^{9} / \mathrm{ml}\right)$ & $2.10 \pm 0.26^{\mathrm{b}}$ & $3.40 \pm 0.26^{\mathrm{a}}$ & $3.07 \pm 0.22^{\mathrm{a}}$ \\
\hline Fertility \%, (ewes lambed/ewes mated, n) & $52.60 \pm 7.17^{\mathrm{b}}$ & $46.50 \pm 7.17^{\mathrm{b}}(47 / 101)$ & $75.00 \pm 6.21^{\mathrm{a}}$ \\
\hline
\end{tabular}

Values of mass motility (0-5), individual motility and live sperm percentages were the best in Assaf semen, and they were significantly higher $(\mathrm{p}<0.05)$ in the semen of Ossimi crossbred rams compared to Ossimi breed. Mass motility value of Ossimi breed in the present study (1.67) was lower than those recorded by Mahmoud (2013) (4.2) on Ossimi rams and (4.3) by Miloud and Karima (2015) on Ouled Djellal rams. Mahmoud (2013) recorded (73.9\%) on Ossimi rams of live sperm, which is in agreement with that reported in the present study on Ossimi breed $(70.90 \%)$, but it is lower than that recorded on Ossimi crosses $(81.67 \%)$. On the same trend, low percentage of live sperm $(65 \%)$ was reported by Miloud and Karima (2015) on Ouled Djellal rams.

Abnormal sperm percentage revealed a significant increase in Ossimi semen compared to Ossimi crossbreds and Assaf semen. The percentages of abnormal sperm in the present study $(6.97-9.80 \%)$ were lower (Table 1) than that stated $(19.7 \%)$ by Mahmoud (2013), but it is higher than the value (4.6\%) recorded by Miloud and Karima (2015).

The fertility rate (ewes lambed per ewes mated) was significantly $(\mathrm{p}<0.05)$ higher in Assaf rams (75\%) compared to Ossimi and Ossimi crossbred rams (52.6 and 46.5\%, respectively, Table 1). Higher fertility rates $(62-77 \%)$ were previously recorded for Ossimi sheep (Aboul-Naga et al.,1992; Hassan et al.,1992; Abdel-Mageed and Abo El-Maaty, 2012). While, Abdel-Mageed (2011) recorded lower rate $(47.5 \%)$ which agreed with the fertility rate of Ossimi sheep and its crosses in this study $(46.4-52.6 \%)$. The proportion of Assaf sheep lambing (68.2 - 74.2 $\%)$ reported by Palacin et al. (2008)is matched with the fertility rate that achieved in the current study.

A total of 14 protein bands were visualized in semen samples (Plate 1 and Table 2). This number is lower than those reported byBarrios et al. (2000)on Rasa aragonesa rams and Jobim et al. (2004) on Hamphsire Down, Corriedale $\times$ Texel who recorded 20 and 21 bands, respectively. The Molecular weights in this study ranged from 29 to $194 \mathrm{kDa}$. Eleven protein bands were determined in Ossimi samples. Meanwhile, semen of Ossimi crossbreds and Assaf rams had 13 protein bands. Protein bands ranged from $78-85$ and $97-107 \mathrm{KDa}$ appeared in almost all breeds. The type of protein 29-33 KDa was more frequent in crossbred rams compared to other breeds. This protein spot 13 (28-30 kDa, pI 3.3-3.5) probably corresponds to $\mathrm{BSP} 30 \mathrm{kDa}$, which isthe most acidic protein of the BSP family (Manjunath and Sairam 1987).

Table 2. The appearance frequency of seminal plasma proteins as affected by breed of rams

\begin{tabular}{lccc}
\hline \multirow{2}{*}{ Molecular Weight(KDa) } & \multicolumn{3}{c}{ Breed } \\
\cline { 2 - 4 } & Ossimi & Ossimi crossbreds & 0.50 \\
$\mathbf{1 9 0 - 1 9 4}$ & 0 & 0 & 0 \\
$\mathbf{1 8 6}$ & 0 & 0.33 & 1.00 \\
$\mathbf{1 5 1 - 1 5 9}$ & 0.33 & 0.67 & 1.00 \\
$\mathbf{1 0 9 - 1 1 4}$ & 0 & 0.33 & 1.00 \\
$\mathbf{9 7 - 1 0 7}$ & 1.00 & 1.00 & 1.00 \\
$\mathbf{7 8 - 8 5}$ & 1.00 & 1.00 & 1.00 \\
$\mathbf{6 1 - 6 5}$ & 0.67 & 1.00 & 0.50 \\
$\mathbf{5 4 - 5 7}$ & 1.00 & 0.33 & 0.50 \\
$\mathbf{4 7 - 5 8}$ & 1.00 & 0.33 & 0.25 \\
$\mathbf{4 5 - 4 9}$ & 0.67 & 1.00 & 1.00 \\
$\mathbf{4 0}$ & 0.33 & 1.00 & 0.75 \\
$\mathbf{3 6 - 3 7}$ & 0.67 & 1.00 & 1.00 \\
$\mathbf{3 3}$ & 0.67 & 1.00 & 0.75 \\
$\mathbf{2 9}$ & 0.33 & 1.00 & \\
\hline
\end{tabular}




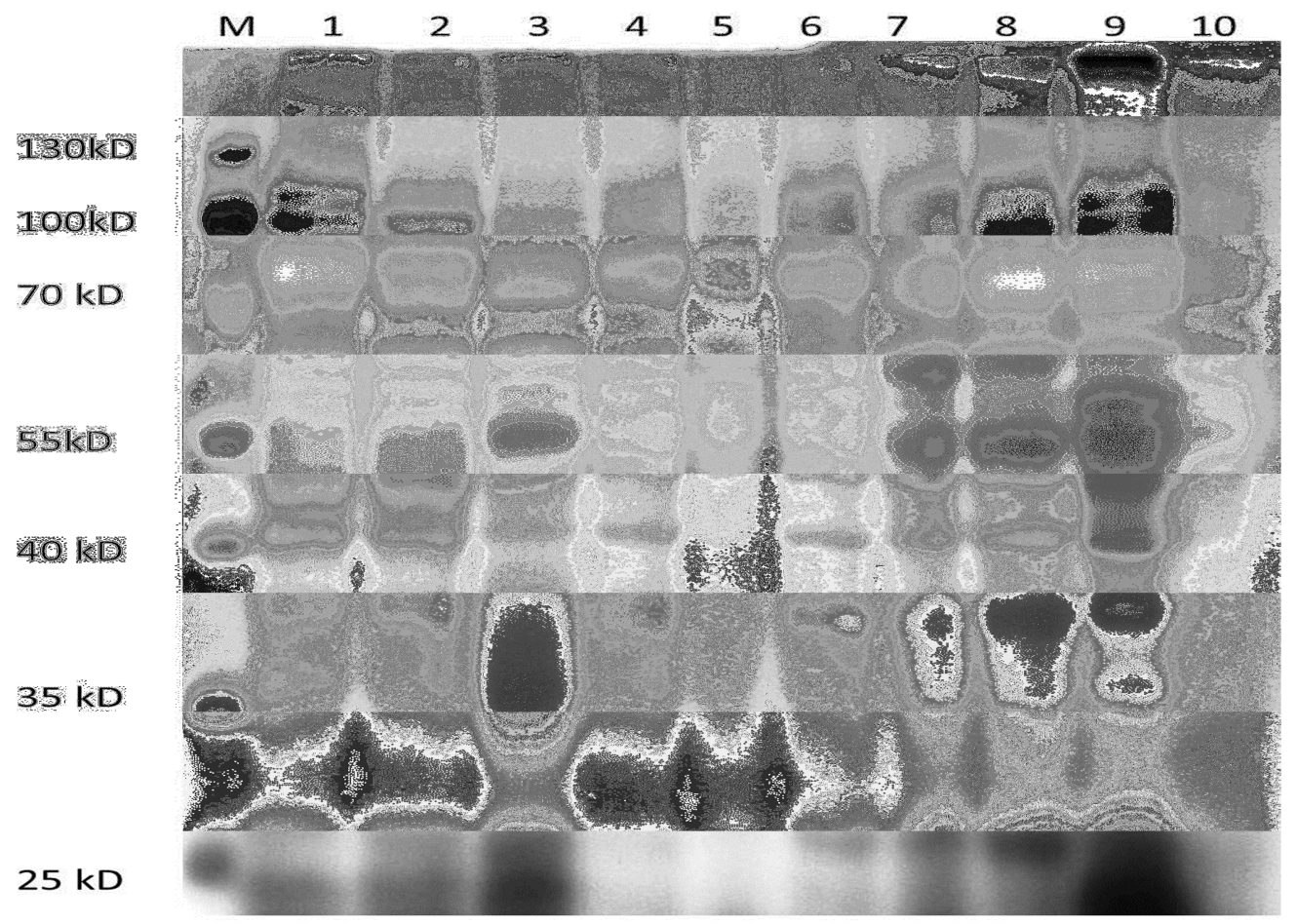

Plate 1. Polyacrylamide gel (SDS-PAGE) of subtropical sheep seminal plasma proteins.(M, Marker; 5, 6, and 10 for Ossimi rams; 4, 7 and 8 for Ossimi crossbreed rams; 1, 2, 3 and 9 for Assaf rams)

The relative content of twelve protein bands varied among the three different breeds. It is noticeable that the $190-194,186$ and $109-114 \mathrm{kDa}$ protein bands cannot be detected in seminal protein samples of Ossimi breed. The relative content of 150159,40 and $29 \mathrm{KD}$ protein bands were much lower (0.33) in Ossimi when compared to its content in Ossimi crossbred and Assaf breeds. So these protein bands could be types of protein which are correlated with the ram fertility. The relative high protein content of 54-57 and $47 \mathrm{KD}$ protein bands in Ossimi breed could explain the significant decrease in sperm parameters and concentration compared to Ossimi crossbred and Assaf breeds.

The present result on $40 \mathrm{KDa}$ showed an increase in the frequency of appearance in Ossimi crossbred and Assaf rams compared to Ossimi rams which could affect the mass motility, sperm motility, live percentage and fertility rate. Jobim et al. (2005) revealed that, clusterin is the major glycoprotein in ram rete testis fluid, with an apparent molecular mass of approximately $40 \mathrm{kDa}$ on SDS-PAGE and an acidic isoelectric point (3.6). Clusterin is found in the testis and epididymis with the highest concentrations and the testicular source of clusterin suggested being Sertoli cells (Blaschukz et al., 1983). The clusterin is found in the seminal plasma, sperm surface of humans and several mammalian species and involved in sperm maturation and possesses heparin-binding sites (Howes et al., 1998; Sylvester et al., 1991 and Pankhurst et al., 1998). Jobim et al. (2004) concluded that cluster in is present in bull seminal plasma and it is related to high semen freezability.
Protein bands 97-107 KDa were present in all studied breeds(100\%). Gatti et al. (1999) descried the transformation of this protein from $105-\mathrm{kDa}$ in the fluid of the caput region to $94 \mathrm{kDa}$ in the epididymis, the caudal fluid and in semen. Jobim et al (2004) suggested that the type of protein $(105 \mathrm{KDa})$ correspond to the germinal form of the angiotensin Iconverting enzyme (gACE).

It is clear from the results of the present study that Assaf rams proved a potential capability for their breeding ability under subtropical conditions. Therefore, it is recommended to widely use Assaf rams under Egyptian conditions as it has a great contribution in milk and meat productions.

\section{REFERENCES}

Abdel-Mageed, I., 2011. Body condition score of Egyptian ewes: does it affect reproductive and productive performances? Egyptian J. Anim. Product., 47 Suppl. Issue, April: 139-150.

Abdel-Mageed, I.I., and A.M. Abo El-Maaty, 2012. The effect of backfat thickness at mating on the reproductive and productive performances of ewes. Small Ruminant Res. 105, 148-153.

Aboul-Naga, A.M., M.B. Aboul-Ela, and F. Hassan, 1992. Manipulation of reproductive activity in subtropical sheep. Small Ruminant Res.7, 51-160.

Aller, J.F., D., Aguilar, T., Vera, Almeida, G.P., and R.H., Alberio, 2012. Seasonal variation in sexual behavior, plasma testosterone and semen characteristics of Argentine Pampinta and Corriedale rams. Spanish Journal of Agricultural Res. 10 (2), 345-352. 
Ashworth P.J.C., R.A., Harrison, N.G.A., Miller, J.M., Plummer, and P.F., Watson, 1994. Survival of ram spermatozoa at high dilution: protective effect of simple constituents of culture media as compared with seminal plasma. Reprod. Fertil Dev. 6, 173-180.

Ayyagari, R.R., A.T., Fazleabas, and M.Y., Dawood, 1987. Seminal plasma proteins of fertile and infertile men analyzed by two-dimensional electrophoresis. Am. J. Obstet. Gynecol. 157 (6), 1528 - 1533.

Baas, J.W., P., Shannon, and P.C., Molan, 1983. Factors in seminal plasma of bulls that affect the viability and motility of spermatozoa. J. Reprod. Fertil. 68 (2), 275 - 280.

Barrios, B., R., Perez, M., Gallego, A., Tato, J., Osada, and T., Muino-Blanco, 2000. Seminal plasma proteins revert the cold-shock damage on ram sperm membrane. Biol. Reprod. 63, 15311538.

Bellin, M.E., H.E., Hawkins, J.N., Oyarzo, and R.J., Ax, R., Vanderboom, 1996. Monoclonal antibody detection of heparin binding proteins on sperm corresponds to increased fertility of bulls. J. Anim. Sci. 74 (1), 173 -182.

Blaschukz, O., K., Burdzy, and I.B., Fritz, 1983. Purification and characterization of a cellaggregating factor (clusterin), the major glycoprotein in ram rete testis fluid. J. Biol. Chem.258(12), 7714-7720.

Boisvert, M., A., Bergeron, C., Lazure, and P., Manjunath, 2004. Isolation and characterization of gelatin-binding bison seminal vesicle secretory proteins. Biol. Reprod. 70 (3), 656 - 661.

Brandon, C.I., G.L., Heusner, A.B., Caudle, and R.A., Fayer-Hosken, 1999. Two-dimensional polyacrylamide gel electrophoresis of equine seminal plasma proteins and their correlation with fertility. Theriogenology52, 863-873.

Cancel, A.M., D.A., Chapman, and G.J., Killian, 1997. Osteopontin is the 55- kilodalton fertilityassociated protein in Holstein bull seminal plasma. Biol. Reprod. 57 (6), 1293 - 1301.

Clark, E.N., M.E., Corron, and H.M., Florman, 1993. Caltrin, the calcium transport regulatory peptide of spermatozoa, modulates acrosomal exocytosis in response to the egg's zona pellucida. J. Biol. Chem. 268 (7), 5309 - 5316.

Cross, N.L., 1993. Multiple effects of seminal plasma on the acrosome reaction of human sperm. Mol. Reprod. Dev. 35 (3), 316 - 323.

Eng, L.E. and G., Oliphant, 1978. Rabbit sperm reversible decapacitation by membrane stabilization with a highly purified glycoprotein from seminal plasma. Biol. Reprod. 19 (5), 1083 1088.

FAO, 2013. FAO Statistical Yearbook. www.FAO.org.

Florman, H.M., and N.L., First, 1988. Regulation of acrosomal exocytosis.II. The zona pellucidainduced acrosome reaction of bovine spermatozoa is controlled by extrinsic positive regulatory elements. Dev. Biol. 128 (2), 464 - 473.

Frazer, G.S., D.M., Bucci, and C.L., Brooks, 1996. Two-dimensional polyacrylamide gel electrophoresis of bovine semen after cryopreservation in half-milliliter straws. Theriogenology46, 1103-1115.

Galal, S., O., Gursoy, and I., Shaat., 2008. Awassi sheep as a genetic resource and efforts for their genetic improvement - a review, Small Ruminant Res. 79, 99-108.

Gatti, J.L., X., Druart, Y., Gue'rin, F., Dacheux, and J. L., Dacheux, 1999. A 105- to 94-kilodalton protein in the epididymal fluids of domestic mammals is angiotensin I-converting enzyme (ACE): evidence that sperm are the source of this ACE. Biol. Reprod. 60, 937-945.

Gerena, M.R.L., D., Irikuda, Y., Urade, N., Eguchi, D.A., Chapman, and G.J., Killian, 1998. Identification of a fertility associated protein in bull seminal plasma as lipocalin-type prostaglandin D synthetase. Biol. Reprod. 58 (3), $826-833$.

Graham, J.K., 1994. Effect of seminal plasma on the motility of the epididymaland ejaculated spermatozoa of the ram and bull during the cryopreservationprocess. Theriogenology 41, 1151-1162.

Hammerstedt, R.H. and J.E., Parks, 1987. Changes in sperm surfaces associated with epididymal transit. J. Reprod. Fertil .Suppl. 34, 133-149.

Hassan, F., M.T., Mousa, A.M., Aboul-Naga, F., ElHommosi, and G., Abd El-Hafez, 1992. Puberty and early mating performance in subtropical fattailed sheep and their crosses. Proceedings of the Second Biennial Conference of the African Small Ruminant Research Network AICC, Arusha, Tanzania 7-11 December.

Howes, E.A., S., Hurst, A., Laslop, and R., Jones, 1998. Cellular distribution and molecular heterogeneity of MAC393antigen (clusterin, beta chain) on the surface membrane of bull spermatozoa. Mol. Hum. Reprod.4, 673-681.

Jobim, M.I.M., E.R., Oberst, C.G., Salbego, D.O., Souza, and V.B., Wald, 2004. Two-dimensional polyacrylamide gel electrophoresis of bovine seminal plasma proteins and their relation with semen freezability. Theriogenology15(61), 255266.

Jobim, M.I.M., E.R., Oberst, C.G., Salbego, V.B., Wald, A.P., Horn, and R.C., Mattos, 2005. BSP A1/A2-like proteins in ram seminal plasma. Theriogenology 63, 2053-2062

Killian, G.J., D.A., Chapman, and L.A., Rogowski, 1993. Fertility-associated proteins in Holstein bull seminal plasma. Biol. Reprod. 49, 1202 - 1207.

Kraus, M., M., Ticha, and V., Jona kova, 2001. Heparin-binding proteins of human seminal plasma homologous with boar spermadhesins. J. Reprod. Immunol. 51 (2), 131 - 144.

Mahmoud, G.B., 2013. Sexual behaviour, testosterone concentration, semen characteristics 
and testes size of Ossimi rams as affected by age and scrotal circumference. Egyptian J. Anim. Product. 50 (2), 53-58.

Manjunath, P. and M.R., Sairam, 1987. Purification and biochimical characterization of three major acid proteins (BSPA1, BSP A2 and BSP A3) from bovine seminal plasma. Biochem. J. 7.685-692.

Manjunath, P., 1984. Gonadotropin release stimulatory and inhibitory proteins in bull seminal plasma. In: "Gonadal Proteins and Peptides and Their Biological Significance". (Eds. Sairam, M.R. and Atkinson, L.E.). World Science Publishing Company, Singapore, pp. 44 - 61.

Manjunath, P. and I., Therien, 2002. Role of seminal plasma phospholipid-binding proteins in sperm membrane lipid modification that occurs during capacitation. J. Reprod. Immunol. 53 (1), 109 119.

Maxwell, W.M.C., R., Welch, and L.A., Johnson, 1997. Viability and membrane integrity of spermatozoa after dilution and flow cytometric sorting in the presence or absence of seminal plasma. Reprod. Fertil. Dev. 8 (8), 1165 - 1178.

Miloud, L. and B.R., Karima, 2015. Variations in semen characteristics rams of Ouled Djellal breed have received an important dietary supplement after regular and intensive collection. Asian Pacific J. Reprod. 4(1), 13-16.

Moreau, R. and P., Manjunath, 1999. Characterization of lipid efflux particles generated by seminal phospholipid-binding proteins. Biochem. Biophys. Acta. 1438 (2), 175 184.

Mortarino, M., G., Tedeschi, A., Negri, F., Ceciliani, L., Gottardi, and G., Maffeo, 1998. Two-dimensional polyacrylamide gel electrophoresis map of bull seminal plasma proteins. Electrophoresis.19, 797-801.

Nauc, V., and P., Manjunath, 2000. Radioimmunoassays for bull seminal plasma proteins (BSP-A1/- 382 A2, BSP-A3, and BSP-30 Kilodaltons), and their quantification in seminal plasma and 383 sperm. Biol. Reprod. 63, 10581066.

NRC, 1985. Nutrient Requirements of Sheep, 6th Edition. NRC, Washington, DC., USA.

Olah, J., S., Kusza, S., Harangi, J., Posta, A., Kovacs, A., Pécsi, C., Budai, and A., Javor, 2013. Seasonal changes in scrotal circumference, the quantity and quality of ram semen in Hungary. Archiv. Tierzucht. 56 (10), 102-108.

Oliveira, M.E.F., O.M., de Almeida, R.O., Pinho, W.R.R., Vicente, and L.F.S., Rodrigues, 2012.
Behavioural and seminal characteristics of Santa Ines rams subjected to successive semen collections in the Amazonian region. Italian J. Anim. Sci. 11, 368-373.

Palacín, I., J-A., Abecia, F., Forcada, A., Casao, J-A., Cebrián, T., Muiño, C., Palacios, and J. M., Pontes, 2008. Effects of exogenous melatonin treatment on out-of-season ram fertility. Italian J.Anim.Sci.7, 199-206.

Pankhurst, J.G., C.A., Bennet, and S.B., EasterbrookSmith, 1998. Characterization of the heparinbinding properties of human clusterin. Biochemistry 37 (14), 4823-4830.

Pursel, V.G., L.A., Johnson, and L.L., Schulman, 1973. Effect of dilution, seminal plasma and incubation period on cold shock susceptibility of boar spermatozoa. J. Anim. Sci. 37 (2), 528 - 531.

Rodríguez-Martínez, H., 2003. Laboratory semen assessment and prediction of fertility: still utopia?. Reprod. Domest. Anim. 38 (4), 312-318.

Roncoletta, M., E.S.C., Morani, and P.H., Franceschin, 2002. $14 \mathrm{kDa}$ seminal plasma protein identification and its relation with bull semen freezability. Theriogenology 57, 479.

SAS, 2004. Ver. 9.1. Qualification Tools User's Guide. SAS Institute, Inc., Cary, NC, USA.

Schoneck, C., J., Braun, and R., Einspanier, 1996. Sperm viability is influenced in vitro by the bovine seminal protein a SFP: effects on motility, mitochondrial activity and lipid peroxidation. Theriogenology 45 (3), 633 - 642.

Sylvester, C., R., Morales, R., Oko, and M.D., Griswold, 1991. Localization of sulfated glycoprotein-2 (clusterin) on spermatozoa and in the reproductive tract of the male rat. Biol. Reprod. 45, 195-207.

Tabbaa, M.J., R.T.,Kridli, M.G., Amashe, and F.S., Barakeh, 2006. Factors affecting scrotal circumference and semen characteristics of Awassi rams. J. Agric. Sci. 2 (3), 243 -250.

Villemure, M., C., Lazure, and P., Manjunath, 2003. Isolation and characterization of gelatin-binding proteins from goat seminal plasma. Reprod. Biol. Endocrinol. 1, 39 - 50.

Vischwanath, R., and P., Shannon, 1997. Do sperm cells age? A review of the physiological changes in sperm during storage at ambient temperature. Reprod. Fertil. Dev. 9 (3), 321 - 331.

Voglmayr, J.K., G., Fairbanks, D.B., Vespa, and J.R., Colella, 1982. Studies on the mechanisms of surface modifications in ram spermatozoa during the final stages of differentiation. Biol. Reprod. 26, 483-500. 
خصائص بروتينات بلازما السائل المنوى وعلاقتها بالخصوبة فى الأغنام تحت الظروف المصرية إبراهيم إبراهيم عبد المجيد، شريف محمد دسوقى

قسم الإنتاج الحيو انى، كلية الزراعة، جامعة القاهرة

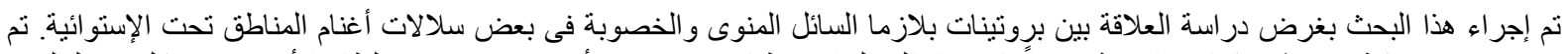

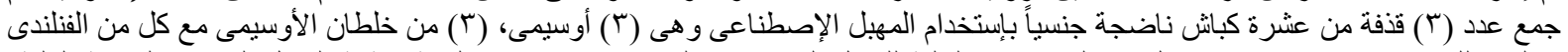

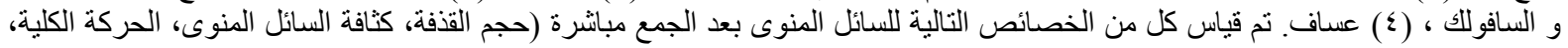

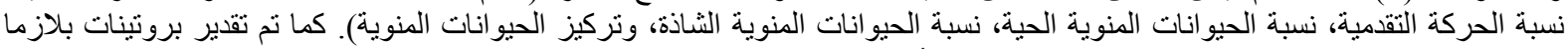

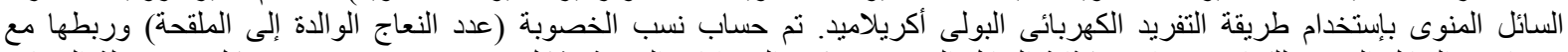

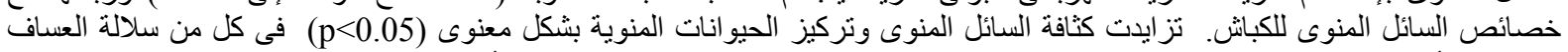

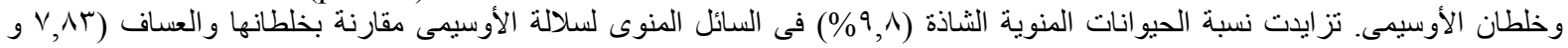

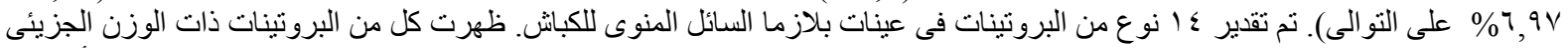

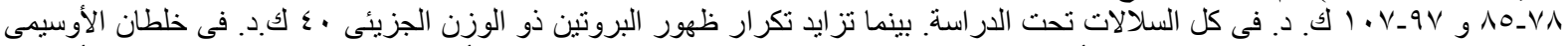

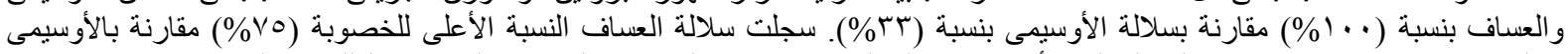

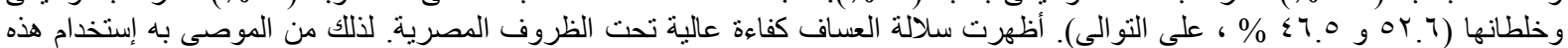

